\title{
REORIENTASI USAHA PEGADAIAN SWASTA SEBAGAI UPAYA KESEIMBANGAN HUBUNGAN HUKUM PARA PIHAK DI INDONESIA
}

\author{
REORIENTATION OF PRIVATE PAWNSHOP BUSINESS \\ AS A BALANCE EFFORTS FOR THE PARTIES LEGAL \\ RELATIONSHIP IN INDONESIA
}

\author{
Siti Malikhatun Badriyah \\ Universitas Diponegoro Semarang \\ Email: sitimalikhatun@live.undip.ac.id \\ R. Suharto \\ Universitas Diponegoro Semarang \\ Email: r.suhartoo@gmail.com \\ Marjo \\ Universitas Diponegoro Semarang \\ Email: marjo.fh.undip@gmail.com
}

\begin{abstract}
Pawnshop businesses are rising in the practice of the business world for a long time ago, but there are no clear rules as guidelines. At present situation, there is regulation regarding private pawnshop with Financial Services Authority regulations. However, many pawnshops businesses do not register to obtain a permit to run a pawnshop business. This has implications of the emergence of various deviations committed by business actors to the principles of pledge and the principles of agreement in general, which results in an imbalance of legal relationships that conflicts with the principle of justice, which results in disputes between the parties. This study aims to determine and analyze the background of the need for reorienting private pawnshops and the occurrence of deviations from the principle of pawnshops. The research method used is socio-legal research. The results showed that the private pawnshop business developed very rapidly, but still very few were registered. In practice, there are many deviations from the principle of pawnshops, especially in the practice of personal liens, especially against the principle of pawn objects that may not be used for the needs of pawn holders because what is owned by the pawn holder is the material rights that provide guarantees.
\end{abstract}

Keywords: Private Pawnshop Business, Balance, Legal relations

\begin{abstract}
Abstrak
Usaha pegadaian marak dilakukan dalam praktik dunia usaha sejak dahulu, namun belum ada aturan yang jelas sebagai pedoman. Saat ini sudah ada pengaturan mengenai pegadaian swasta dengan peraturan Otoritas Jasa Keuangan. Namun demikian masih banyak usaha pegadaian yang tidak melakukan pendaftaran untuk mendapatkan izin menjalankan usaha pegadaian. Hal ini berimplikasi munculnya berbagai penyimpangan yang dilakukan oleh para pelaku usaha terhadap prinsipprinsip gadai maupun prinsip-prinsip perjanjian pada umumnya yang bermuara pada ketidakseimbangan hubungan hukum yang bertentangan dengan prinsip keadilan, yang mengakibatkan sengketa antara para pihak. Penelitian ini bertujuan
\end{abstract}


untuk mengetahui dan menganalisis latar belakang diperlukannya reorientasi pegadaian swasta dan terjadinya penyimpangan terhadap prinsip pegadaian. Metode penelitian yang digunakan adalah socio legal research. Hasil penelitian menunjukkan bahwa usaha pegadaian swasta mengalami perkembangan sangat pesat, namun masih sangat sedikit yang sudah terdaftar. Dalam praktik banyak terdapat penyimpangan terhadap prinsip pegadaian, terutama pada praktik gadai perorangan, khususnya terhadap prinsip benda gadai tidak boleh digunakan untuk keperluan pemegang gadai, karena yang dimiliki oleh pemegang gadai adalah hak kebendaan yang bersifat memberikan jaminan.

\section{Kata Kunci: Usaha Pegadaian Swasta, keseimbangan, hubungan hukum}

\section{PENDAHULUAN}

Penggunaan jaminan dalam dunia usaha senantiasa mengalami perkembangan dari waktu ke waktu. Hal ini tidak terhindarkan, karena berbagai kegiatan usaha pun mengalami perkembangan pesat dalam kehidupan masyarakat. Kegiatan-kegiatan usaha yang dilakukan oleh pelaku bisnis pada umumnya didasarkan perjanjian antara para pihak, antar pelaku usaha maupun antara pelaku usaha dengan konsumen. Akibatnya berbagai perjanjian pun mengalami perkembangan pesat, antara lain perjanjian utang piutang. Perjanjian ini terjadi karena kesepakatan para pihak. Sepakat untuk pihak yang mengikatkan diri mengandung asas kebebasan berkontrak. ${ }^{1}$

Dalam perjanjian utang piutang pada umumnya kreditor menghendaki adanya jaminan, untuk memberikan keyakinan kepada kreditor terhadap pelaksanaan prestasi debitor. ${ }^{2}$ Pada perjanjian utang-piutang dengan pihak nasabah selaku debitor, maka pihak kreditor perlu mendapatkan jaminan atas piutang yang dipinjamkan oleh pihak kreditor, yaitu dengan cara mensyaratkan adanya penyerahan suatu objek dari debitor kepada pihak kreditor. ${ }^{3}$ Pentingnya jaminan ini juga dirasakan di berbagai negara. Sumit Agarwal dkk. ${ }^{4}$ mengemukakan bahwa Jaminan awal merupakan faktor penting untuk memprediksi default kredit. Secara khusus individu yang memiliki agunan lebih tinggi memiliki risiko yang lebih rendah. Jaminan digunakan untuk membantu memitigasi risiko informasi asimetri antara kreditor dan debitor. ${ }^{5}$

Salah satu jaminan yang sering digunakan dalam dunia usaha adalah jaminan terhadap benda bergerak dengan menggunakan lembaga jaminan gadai."The role of pawnshops as basic creditors of citizens greatly increases. Successfully functioning on the market of the consumer crediting, pawnshops maintain and increase the population's payment capacity. It activates the aggregate demand in the economy and acts as an additional impulse of the economic development of the country". ${ }^{6}$

Gadai merupakan salah satu jaminan kebendaan. Jaminan kebendaan yang khusus ini adalah penunjukan/penentuan atas benda tertentu milik debitor atau milik pihak

\footnotetext{
${ }^{1}$ Mariam Darus Badrulzaman, 2018, Hukum Harta Kekayaan Indonesia Di Dalam Perkembangan,Cet. Ke-1, PT Citra Aditya Bakti, Bandung, hlm.7.

${ }^{2}$ Siti Malikhatun Badriyah, 2016, Problematika Pembebanan Hak Tanggungan Dengan Objek Tanah Yang Belum Bersertipikat, Masalah - Masalah Hukum, Vol. 45 No. 3, hlm. 173-80.

${ }^{3}$ Ainon Marziah, Sri Walny Rahayu, and Iman Jauhari, 2019,Pembuktian Risalah Lelang Bagi Pemenang Eksekusi Hak Tanggungan (Proof The Minutes Of Auction For The Winner Of Execution Of Mortgage Rights). Jurnal IUS, Kajian Hukum dan Keadilan, Volume 7, no. 2 hlm. 226.

${ }^{4}$ Sumit Agarwal et al., 2015, Collateral Pledge, Sunk-Cost Fallacy and Mortgage Default, Journal of Financial Intermediation 24 (4), doi:10.1016/j.jfi.2014.10.001. 636.

${ }^{5}$ Christopher Gan et al.,2012, Credit Scoring in Mortgage Lending: Evidence from China. International Journal of Housing Markets and Analysis, 5 (4), doi:10.1108/17538271211268457.334-350.

${ }^{6}$ M.V. Savina and P.V. Solodukha G.I. Andryushchenko, A.M. Andryushchenko, A.N. Maloletko. 2017. Risks of Developing the Pawnshops Market in the Russian Federation. International Journal of Applied Business and Economic Research, Vol. 15, No. 8, hlm. 23.
} 
ketiga yang untuk menjamin pelaksanaan prestasi debitor kepada kreditor. Jika debitor wanprestasi atas pembayaran hutangnya, hasil dari benda objek jaminan tersebut harus lebih dahulu dibayar kepada kreditor pemegang gadai sebagai kreditor preference. ${ }^{7}$ Apabila ada sisa baru dibagikan kepada kreditor lain (kreditor konkuren). Pasal 1150 Kitab Undang-Undang Hukum Perdata (KUH Perdata) menyatakan bahwa gadai adalah suatu hak yang diperoleh seorang kreditor atas suatu barang bergerak yang diserahkan kepadanya oleh seorang debitor atau orang lain atas namanya dan memberikan kekuasaan kepada kreditur untuk mengambil pelunasan piutangnya dari hasil penjualan barang-barang tersebut didahulukan dari kreditor lainnya.

Definisi gadai juga disebutkan dalam Pasal 1 Angka 10 Peraturan Otoritas Jasa Keuangan Nomor 31 /POJK.05/2016 Tentang Usaha Pegadaian yaitu bahwa "gadai adalah suatu hak yang diperoleh Perusahaan Pegadaian atas suatu barang bergerak, yang diserahkan kepadanya oleh nasabah atau oleh kuasanya, sebagai jaminan atas pinjamannya, dan yang memberi wewenang kepada Perusahaan Pegadaian untuk mengambil pelunasan pinjaman dari barang itu dengan mendahului kreditur-kreditur lain, dengan pengecualian biaya untuk melelang atau menjual barang tersebut dan biaya untuk menyelamatkan barang tersebut yang dikeluarkan setelah barang itu diserahkan sebagai gadai, biaya-biaya mana harus didahulukan." Dari definisi gadai sebagaimana disebutkan dalam POJK tentang Usaha Pegadaian menunjukkan bahwa pihak pemegang gadai adalah perusahaan.

Gadai meliputi gadai yang dilakukan perum pegadaian dan gadai swasta. Pasal 1 Angka 2 POJK Nomor 31/POJK.05/2016 menyebutkan bahwa "Perusahaan Pegadaian adalah perusahaan pegadaian swasta dan perusahaan pegadaian pemerintah yang diatur dan diawasi oleh Otoritas Jasa Keuangan. Perusahaan Pegadaian Swasta adalah badan hukum yang melakukan Usaha Pegadaian Pasal 1 Angka 3 POJK Nomor 31 / POJK.05/2016)". Dari Pasal tersebut menunjukkan bahwa Pemegang gadai harus perusahaan yang berbentuk Badan Hukum.

Pasal 1 angka 3 POJK 31/POJK.05/2016 mendefinisikan "Perusahaan Pegadaian Swasta adalah badan hukum yang melakukan Usaha Pegadaian". Angka 4 mendefinisikan "Perusahaan Pegadaian Pemerintah adalah PT Pegadaian (Persero) sebagaimana dimaksud dalam Staatsblad Tahun 1928 No 81 tentang Pandhuis Regleement dan Peraturan Pemerintah No 51 Tahun 2011 tentang Perubahan Bentuk Badan Hukum Perusahaan Umum (Perum) Pegadaian menjadi Perusahaan Perseroan (Persero)".

Gadai tidak asing lagi bagi masyarakat, bahkan saat ini mengalami perkembangan pesat. Gadai pada awal perkembangannya merupakan pembiayaan untuk membantu kebutuhan masyarakat menengah ke bawah, namun saat ini tidak hanya digunakan oleh masyarakat menengah ke bawah tetapi menjangkau semua lapisan masyarakat. ${ }^{8}$

Gadai meliputi gadai yang dilakukan perum pegadaian dan gadai swasta. Sebagai salah satu usaha pegadaian, gadai swasta sebenarnya sudah banyak dilakukan. Gadai swasta pada awalnya tidak ada pengaturan dan pengawasan, sehingga berakibat sering menimbulkan kerugian para pihak karena adanya berbagai penyimpangan terhadap prinsip-prinsip gadai. Sejak keluarnya Peraturan Otoritas Jasa Keuangan No 31 /

\footnotetext{
${ }^{7}$ Dilva Muzdaliva Sawotong. 2014. Jaminan Kebendaan Pada PT. Pergadaian Terhadap Barang Yang Digadaikan. Lex Privatum, vol 2, no. 1 hlm. 36-46.

${ }^{8}$ Lastuti Abubakar and Tri Handayani, 2017, Telaah Yuridis Perkembangan Regulasi Dan Usaha Pergadaian Sebagai Pranata Jaminan Kebendaan. Jurnal Bina Mulia Hukum 2 (35), doi:10.23920/jbmh. v2n1.7. hlm, 80-92.
} 
POJK.05/2016 Tentang Usaha Pegadaian, maka gadai swasta dilegalkan. Pertimbangan pemerintah adalah untuk lebih memudahkan pengawasan, sehingga dapat memberikan kepastian dan perlindungan hukum terhadap para pihak.

Dalam kehidupan masyarakat ternyata pendaftaran usaha pegadaian swasta belum banyak dilakukan. Praktik pegadaian swasta ini banyak dijalankan karena syaratnya sangat mudah dan sederhana. Antara lain benda gadai seperti kendaraan bermotor seringkali digunakan oleh pemegang gadai untuk keperluan sehari-hari bahkan kadangkala digunakan sebagai usaha. Padahal ada prinsip jaminan bahwa benda gadai tidak memberikan hak kepada pemegang gadai untuk menggunakan dan menikmati bendanya. Hal ini berpotensi besar menimbulkan kerugian para pihak. Penelitian ini bertujuan untuk memperoleh bukti-bukti mengenai legalitas usaha pegadaian swasta dan keseimbangan hubungan hukum para pihak dalam pelaksanaan gadai swasta.

Metode penelitian yang digunakan adalah socio legal research. Dalam hal ini dilakukan penelitian kepustakaan, dengan metode studi dokumen, untuk memperoleh data sekunder. Data sekunder tersebut diperoleh dengan mengkaji bahan hukum primer, sekunder dan tersier yang berkaitan dengan pegadaian swasta sebagai upaya keseimbangan hubungan hukum para pihak di Indonesia. Di samping itu juga dilakukan penelitian lapangan dengan teknik wawancara. Narasumber dalam penelitian ini adalah Otoritas Jasa Keuangan. Teknik analisis data dilakukan secara kualitatif.

\section{PEMBAHASAN}

\section{Penyimpangan Asas Hukum Perjanjian dan Prinsip Jaminan dalam Pelaksanaan Pegadaian Swasta}

Pesatnya perkembangan bisnis di Indonesia menjadikan makin banyak pelaku usaha maupun masyarakat (konsumen) membutuhkan dana dalam pemenuhan kebutuhan baik konsumtif maupun produktif. Dana tersebut dapat berasal dari diri sendiri maupun pihak lain. Keberadaan lembaga yang menyediakan modal (pinjaman) menjadi sangat penting bagi masyarakat. Perusahaan gadai merupakan salah satu lembaga yang menyediakan pinjaman yang dimaksud. Perusahaan gadai menawarkan kemudahan mendapatkan pinjaman sehingga menjadi solusi alternatif bagi masyarakat di tengah sulitnya mendapatkan pinjaman dari lembaga penyedia pinjaman seperti bank. ${ }^{9} \mathrm{Oleh}$ karena itu usaha pegadaian swasta bertumbuh dengan pesat di samping pegadaian pemerintah.

Berdasarkan data Otoritas Jasa Keuangan (OJK) mencatat sebanyak 585 perusahaan gadai swasta belum memiliki izin dan terdaftar. Hingga Juli 2018 baru ada 24 perusahaan gadai swasta yang sudah memiliki izin dan terdaftar. Dari catatan Otoritas Jasa Keuangan (OJK) saat ini ada sekitar 600 pelaku usaha gadai swasta yang berdiri di Indonesia. Jumlah tersebut merupakan pelaku bisnis gadai yang memiliki modal besar. Di luar itu, tentu ada pelaku-pelaku usaha kecil yang juga menjalankan bisnis ini. Maraknya bisnis gadai di Indonesia tidak lepas dari tingginya permintaan di masyarakat terhadap kebutuhan pendanaan yang mudah. ${ }^{10}$ Dengan gadai, masyarakat bisa mendapatkan dana secara cepat dengan menjaminkan barang-barang yang dimilikinya, antara lain barang

\footnotetext{
${ }^{9}$ Annisa Hanifah, Budi Santoso, and Ismail Navianto,2018, "Urgensi Pengaturan Perusahaan Gadai Swasta Dengan Sistem Online, Al-Mustashfa, Jurnal Penelitian Hukum Ekonomi Syariah, vol. 3, no. 1, hlm. 30-40.

${ }^{10}$ Novianti Ekatama, 2014, Prospek Usaha Pergadaian dalam Menghadapi Lembaga Perkreditan di Indonesia. Jurnal Repertorium, vol. 1, no. 2, hlm. 5-12.
} 
elektronik, kendaraan bermotor, sepeda, perhiasan emas, dan sebagainya. Permintaan pasar yang tinggi membuat bisnis ini menjadikan pelaku usaha berminat besar untuk menjalankan bisnis pegadaian.

Bisnis Gadai di Indonesia sudah ada sejak zaman kolonialisme pada pertengahan abad ke-18. Hal ini dapat dilihat dari situs Bank Indonesia. Pada 1746 VOC mendirikan De Bank van Leening yang kemudian menjadi De Bank Courant en Bank van Leening pada tahun 1752, yang merupakan bank pertama yang lahir di Hindia Belanda dan menjadi cikal bakal industri perbankan di Indonesia. Pada 1811, Pemerintah Inggris mengambil alih dan membubarkan Bank Van Leening. Masyarakat pun diberi keleluasaan untuk mendirikan usaha pegadaian sendiri. Meskipun bisnis gadai banyak dijalankan oleh masyarakat, namun bisnis gadai pertama yang berbadan hukum berdiri di Sukabumi pada 1 April 1901. Saat itu didirikan Rumah Gadai Negara melalui ordonansi yang diterbitkan dengan Staatsbladno 131. Tanggal 1 April ini pun dicatat sebagai hari jadi Pegadaian. Selanjutnya, dikeluarkan izin-izin usaha Rumah Gadai Negara di berbagai tempat dengan berbagai Staatsblad lainnya. Dalam hal ini, penyelenggaraan rumah gadai hanya boleh dilakukan oleh negara dan pihak swasta dilarang untuk menyelenggarakannya.

Pada tahun 1905 Pegadaian berbentuk Jawatan, kemudian pada 1961berubah menjadi PN (Perusahaan Negara) berdasarkan Peraturan Pemerintah Pengganti Undang-Undang No 19 Tahun 1960 dan PP No.178 Tahun 1961. Bentuk badan hukum Pegadaian kembali mengalami perubahan, pada1969 status Pegadaian sebagai PN berubah menjadi Perusahaan Jawatan (PERJAN) berdasarkan Peraturan Pemerintah No.7 Tahun 1969. Pada1990, bentuk badan hukum Pegadaian kembali mengalami perubahan dari PERJAN menjadi Perusahaan Umum (PERUM) berdasarkan PP No.10 Tahun 1990 yang diperbarui dengan PP No.103 tahun 2000. Pada tanggal 1 April 2012, bentuk badan hukum PERUM berubah menjadi Persero berdasarkan PP No. 51 Tahun 2011 dan sampai sekarang. ${ }^{11}$ Jadi selama ini hanya ada pegadaian pemerintah yang memiliki legalitas usaha pegadaian. Hal ini tidak berarti bahwa tidak ada usaha pegadaian swasta. Dalam praktik banyak terdapat usaha pegadaian swasta. Akibatnya banyak terjadi penyimpangan terhadap prinsip-prinsip gadai dan perjanjian pada umumnya, bahkan gadai online.

Makin maraknya kegiatan bisnis pegadaian dan munculnya berbagai penyimpangan mendorong pemerintah untuk mengatur pegadaian swasta ini. Pada tahun 2016 Otoritas Jasa Keuangan (OJK) mengeluarkan Peraturan Otoritas Jasa Keuangan No 31 Tahun 2016 tentang Usaha Pegadaian (POJK Usaha Pegadaian). Pertimbangan dikeluarkannya POJK tersebut adalah:

1. Untuk memperluas layanan jasa keuangan melalui penyelenggaraan usaha pegadaian dalam rangka meningkatkan inklusi keuangan bagi masyarakat menengah ke bawah dan usaha mikro, kecil, dan menengah, perlu memperluas layanan jasa keuangan melalui penyelenggaraan usaha pegadaian;

2. Untuk memberikan landasan hukum bagi Otoritas Jasa Keuangan dalam mengawasi usaha pegadaian di Indonesia dalam rangka penyelenggaraan usaha pegadaian yang memberikan kemudahan akses terhadap pinjaman, khususnya bagi masyarakat menengah ke bawah dan usaha mikro, kecil, dan menengah;

${ }^{11}$ Luthfia Ayu Azanella, 2018,Perjalanan Bisnis Gadai Dari Masa Ke Masa, Kompas.Com, https://ekonomi.kompas.com/read/2018/05/30/070000126/perjalanan-bisnis-gadai-dari-masa-ke-masa-.diakses tanggal 22 Agustus 2019.

\section{IUS Kajian Hukum dan Keadilan}


3. Perlunya landasan hukum untuk pengawasan usaha pegadaian untuk menciptakan usahapegadaianyangsehat,memberikankepastianhukumbagipelakuusahapegadaian, dan perlindungan kepada konsumen.

Pasal 1 Angka 1 POJK Usaha Pegadaian menyebutkan bahwa Usaha Pegadaian adalah segala usaha menyangkut pemberian pinjaman dengan jaminan barang bergerak, jasa titipan, jasa taksiran, dan/atau jasa lainnya, termasuk yang diselenggarakan berdasarkan prinsip syariah. Dengan demikian Usaha Pegadaian ini menggunakan prinsip gadai sebagaimana diatur dalam Pasal $1150 \mathrm{KUH}$ Perdata. Perjanjian gadai menimbulkan perikatan yang merupakan hubungan hukum antara dua pihak. Pihak-pihak dalam Gadai adalah pihak Perusahaan Pegadaian sebagai Pemegang Gadai (penerima jaminan) dan pihak nasabah sebagai Pemberi Gadai (pihak yang menyerahkan benda gadai) atau oleh kuasanya.

Perusahaan Pegadaian adalah perusahaan pegadaian swasta dan perusahaan pegadaian pemerintah yang diatur dan diawasi oleh Otoritas Jasa Keuangan (Pasal 1 Angka 2 POJK Usaha Pegadaian). Perusahaan Pegadaian Swasta adalah badan hukum yang melakukan Usaha Pegadaian (Pasal 1 Angka 3 POJK Usaha Pegadaian). Perusahaan Pegadaian Pemerintah adalah PT Pegadaian (Persero) sebagaimana dimaksud dalam Staatsblad Tahun 1928 No 81 tentang Pandhuis Regleement dan Peraturan Pemerintah No 51 Tahun 2011 tentang Perubahan Bentuk Badan Hukum Perusahaan Umum (Perum) Pegadaian menjadi Perusahaan Perseroan (Persero) (Pasal 1 Angka 4 POJK Usaha Pegadaian).

Dalam peraturan tersebut diatur mengenai usaha pegadaian swasta. Dalam peraturan tersebut, pelaku usaha swasta diwajibkan mendapatkan izin. Sampai Mei 2018, baru ada 24 perusahaan gadai yang telah terdaftar dan memperoleh ijin dari OJK.

Tabel 1 Perusahaan Yang Terdaftar

\begin{tabular}{llll} 
No & Daerah/Kota & \multicolumn{2}{l}{ Nama Perusahaan } \\
1 & Semarang & 1. & KSP Mandiri Sejahtera Abadi; \\
& & 2. & KSU Dana Usaha; \\
& & 3. & PT Mitra Kita di Semarang; \\
& 4. & UD Ijab di Semarang; \\
& 5. & CV Soverino Eka Sakti di Semarang, \\
& 6. & CV Prima Perkasa di Semarang, \\
\hline 2 & Jakarta & 1. & PT Mas Agung Sejahtera PT Surya \\
& & 2. & Pilar Kencana \\
& & 3. & Solusi Gadai \\
& & 4. & PT Pusat Gadai Indonesia \\
\hline 3 & Tangerang & 1. & PT Svaraputra Penjuru Vijaya \\
& & & \\
\hline 4 & Medan & 1. & PT Persada Arihta Mandiri \\
\hline 5 & Yogyakarta & 2. & Padai Murah Jogja \\
& & &
\end{tabular}

Sumber: Data yang diolah Tahun 2018 
Tabel 2 Perusahaan Yang Berijin

\begin{tabular}{lll} 
No & \multicolumn{1}{c}{ Daerah } & \multicolumn{1}{c}{ Nama Perusahaan } \\
1 & Jakarta & 1. PT Pegadaian (Persero) \\
& & $\begin{array}{l}\text { 2. PT HBD Gadai Nusantara } \\
\text { 3. PT Gadai Pinjam Indonesia di Jakarta, PT Sarana } \\
\end{array}$ \\
& & Gadai Prioritas \\
\hline 2 & Kepulauan Riau & PT Mitra Gadai Sejahtera Kepri \\
\hline 3 & Semarang, & PT Sili Gadai Nusantara \\
\hline 4 & Bekasi, & 1. PT Jawa Barat Gadai Sejati \\
& & 2. PT Jasa Gadai Syariah \\
\hline 5 & Yogyakarta, & PT Pegadaian Dana Sentosa \\
\hline 6 & Bandung, & PT Sahabat Gadai Sejati \\
\hline
\end{tabular}

Sumber: Data yang diolah Tahun 2018

Dari data dalam tabel 1 mengenai perusahaan gadai swasta yang terdaftar dan tabel 2 mengenai perusahaan yang memiliki ijin dapat dilihat bahwa masih sangat sedikit dibandingkan dengan pegadaian swasta yang tidak terdaftar. Terhadap perusahaan gadai swasta yang tidak terdaftar tersebut sangat sulit dilakukan pengawasan. OJK tidak memiliki kewenangan untuk mengawasi, sehingga masih terdapat praktik gadai swasta yang tidak sesuai dengan prinsip-prinsip pegadaian dan menyimpang dari asasasas hukum jaminan pada umumnya serta hukum perjanjian.

Hubungan hukum para pihak dalam gadai dasarnya adalah perjanjian, yaitu perjanjian gadai. Perjanjian gadai ini bersifat konsensual, obligatoir dan bentuknya bebas. Perjanjian gadai merupakan perjanjian yang bersifat accessoir, artinya perjanjian gadai merupakan perjanjian ikutan (tambahan) dari perjanjian pokok. Dengan demikian ada atau tidak adanya gadai tergantung dari ada atau tidak adanya perjanjian pokoknya

Pasal 1150 KUH Perdata menyebutkan bahwa "gadai adalah suatu hak yang diperoleh seorang kreditor atas suatu barang bergerak yang diserahkan kepadanya oleh seorang debitor atau orang lain atas namanya dan memberikan kekuasaan kepada kreditor untuk mengambil pelunasan piutangnya dari hasil penjualan barang-barang tersebut didahulukan dari kreditor lainnya."Pasal 1 Angka 10 Peraturan Otoritas Jasa Keuangan Nomor 31 /POJK.05/2016 Tentang Usaha Pegadaian menyebutkan bahwa "gadai adalah suatu hak yang diperoleh Perusahaan Pegadaian atas suatu barang bergerak, yang diserahkan kepadanya oleh nasabah atau oleh kuasanya, sebagai jaminan atas pinjamannya, dan yang memberi wewenang kepada Perusahaan Pegadaian untuk mengambil pelunasan pinjaman dari barang itu dengan mendahului kreditur-kreditur lain, dengan pengecualian biaya untuk melelang atau menjual barang tersebut dan biaya untuk menyelamatkan barang tersebut yang dikeluarkan setelah barang itu diserahkan sebagai gadai, biaya-biaya mana harus didahulukan."

Dari definisi gadai tersebut di atas menunjukkan bahwa dalam gadai terdapat unsurunsur: 
1. Gadai merupakan hak kebendaan yang bersifat memberikan jaminan. Artinya bahwa fungsi gadai adalah untuk menjamin pelaksanaan prestasi debitor kepada debitor. Dengan demikian penyerahan benda gadai dari pemberi gadai kepada pemegang gadai adalah untuk menguasai benda gadai sebagai jaminan. Karena sifatnya merupakan hak jaminan bukan hak kebendaan yang bersifat memberikan kenikmatan, maka tidak memberikan hak kepada pemegang hak jaminan (pemegang gadai) untuk menikmati dan menggunakan benda gadai. Hak gadai merupakan hak kebendaan tidak secara eksplisit disebutkan pada Pasal 1150 KUH Perdata. Hal ini secara implisit tersirat dari ketentuan Pasal 1152 Ayat (3) KUH Perdata yang menyebutkan bahwa "Pemegang gadai memiliki hak revindikasi dari Pasal 1977 ayat 2 KUH Perdata apabila barang gadai hilang atau dicuri. Revindikasi adalah hak menuntut kembali benda yang hilang atau dicuri. Hak revindikasi ini merupakan salah satu karakteristik hak kebendaan. Oleh karena itu dapat disimpulkan bahwa gadai merupakan hak kebendaan.

2. Gadai lahir karena penyerahan kekuasaan atas barang gadai kepada kreditor pemegang gadai. Penyerahan benda gadai dari tangan pemberi gadai kepada pemegang gadai ini bersifat mutlak untuk terjadinya gadai. Dengan demikian harus ada penyerahan nyata, yaitu penyerahan langsung dari tangan ke tangan. Apabila penyerahan dilakukan secaraconstitutumpossessoriummakatidakmenimbulkangadai.Penyerahanconstitutum possessorium adalah penyerahan dengan melanjutkan penguasaan atas benda. Dengan penyerahan semacam itu maka benda gadai tetap berada dalam kekuasaan pemberi gadai. Hal ini bertentangan dengan syarat inbezitstelling dalam gadai sebagaimana ditentukan dalam Pasal 1132 Ayat (2) KUH Perdata bahwa tidak ada hak gadai jika barang gadai dibiarkan tetap berada di dalam kekuasaan debitor atau pemberi gadai atau kembali dalam kekuasaan debitor atau pemberi gadai atas kemauan kreditor pemegang gadai.

3. Penyerahan benda gadai yang dilakukan oleh debitor pemberi gadai atau orang lain atas nama debitor kepada kreditor pemegang gadai;

4. Benda yang menjadi objek gadai adalah benda bergerak; Pasal 499 KUH Perdata menentukan bahwa "benda adalah semua barang dan hak yang dapat menjadi objek hak eigendom". Barang menunjukkan benda bertubuh, sedangkan hak menunjukkan benda tidak berubah (piutang). Benda bergerak adalah benda yang dapat dipindahkan atau dapat berpindah sendiri dari satu tempat ke tempat lainnya.

5. Subjek gadai adalah pemberi gadai dan pemegang gadai. Pemberi gadai adalah pihak yang menyerahkan benda bergerak sebagai jaminan bagi pelaksanaan prestasi debitor kepada kreditor. Pihak pemegang gadai adalah pihak yang memiliki piutang yang pelaksanaannya dijamin dengan gadai. Pemegang gadai dalam hal ini merupakan perusahaan yang berbentuk Badan Hukum sebagaimana disebutkan dalam Pasal 1 Angka 3 POJK Nomor 31/POJK.05/2016. Pemberi gadai adalah nasabah Perusahaan Pegadaian. Nasabah adalah orang perseorangan ataubadan usaha yang menerima Uang Pinjaman dengan jaminan berupa Barang Jaminan dan/atau memanfaatkan layanan lainnya yang tersedia di Perusahaan Pegadaian (Pasal 1 Angka 15 POJK POJK Nomor 31 /POJK.05/2016) .

6. Kreditor pemegang gadai berhak untuk mengambil pelunasan dari barang gadai lebih dahulu daripada kreditor-kreditor lainnya. Hal ini sebagai konsekuensi hak preferen yang dimiliki oleh pemegang jaminan kebendaan, termasuk Pemegang Gadai. 
Dalam perjanjian terdapat asas-asas hukum perjanjian yang meliputi asas konsensualisme, asas kebebasan berkontrak dan asas pacta sunt servanda.

Asas konsensualisme berkaitan dengan terjadinya perjanjian. Perjanjian terjadi karena ada kesepakatan para pihak. Hal ini secara implisit terdapat dalam Pasal 1320 KUH Perdata mengenai syarat sahnya perjanjian yang meliputi: 1) kesekatan, 2) kecakapan, 3) suatu hal tertentu, dan 4) sebab yang halal. Syarat sahnya perjanjian ini berbeda dengan terjadinya perjanjian. Terjadinya perjanjian adalah pada saat terjadi kesepakatan (persesuaian kehendak) antara para pihak.

Asas Kebebasan berkontrak berkaitan dengan isi perjanjian, yang secara implisit terdapat dalam Pasal 1338 KUH Perdata. Semua perjanjian yang dibuat secara sah berlaku sebagai undang-undang bagi para pihak. Dari kata semua mengandung makna bahwa para pihak memiliki kebebasan untuk menentukan pihak-pihak dalam perjanjian, isi perjanjian, bentuk perjanjian, ketentuan hukum yang berlaku terhadap perjanjian. Sahnya perjanjian adalah jika perjanjian telah memenuhi syarat sahnya perjanjian sebagaimana ditentukan dalam Pasal 1320 KUH Perdata yaitu kesepakatan, kecakapan, suatu hal tertentu (objeknya tertentu), sebab yang halal.

Asas pacta sunt servanda, yaitu asas mengikatnya perjanjian bahwa perjanjian yang dibuat secara sah berlaku sebagai undang-undang bagi para pihak. Hal ini secara jelas ditentukan dalam Pasal 1338 KUH Perdata. Adanya ketentuan tersebut berarti perjanjian tersebut mengikat dan harus dilaksanakan oleh kedua belah pihak sebagaimana mengikatnya undang-undang.

Pada Hukum jaminan juga terdapat asas-asas hukum jaminan yang dapat tersirat dalam Pasal 1131 dan 1132 KUH Perdata. Pasal 1131 KUH Perdata menyebutkan bahwa "segala kebendaan seorang debitor, baik yang bergerak maupun tidak bergerak, baik yang sudah ada maupun yang baru akan ada di kemudian hari, menjadi jaminan untuk segala perikatan pribadi debitor tersebut". Pasal 1132 KUH. Perdata menyebutkan bahwa "kebendaan tersebut dalam pasal 1131 menjadi jaminan bersama bagi para kreditor dan hasil penjualan kebendaan tersebut dibagi diantara para kreditor seimbang menurut besar kecilnya piutang mereka masing-masing, kecuali ada alasan-alasan yang sah untuk mendahulukan piutang yang satu dari piutang yang lain".

Dari Pasal 1131 dan 1132 KUH. Perdata dapat disimpulkan adanya asas-asas:

1) asas schuld dan haftung, berarti bahwa "setiap orang bertanggung jawab terhadap utangnya, tanggung jawab ini berupa menyediakan kekayaannya baik benda bergerak maupun benda tidak bergerak. jika perlu dijual untuk melunasi utang-utangnya".

2) asas kepercayaan, berarti bahwa "setiap orang yang memberikan utang kepada orang lain harus percaya bahwa debitor akan memenuhi prestasinya di kemudian hari".

3) asas moral, berarti bahwa "setiap orang wajib memenuhi janjinya". Asas moral ini dikuatkan sebagai norma hukum.

4) asas paritas kreditorium

"seseorang yang mempunyai beberapa kreditor, maka kedudukan para kreditor adalah sama".

5) asas keseimbangan

"masing-masing kreditor memperoleh piutangnya seimbang dengan piutang kreditor yang lain".

6) asas umum, yaitu "adanya kesamaan hak parakreditor atas harta kekayaan debitornya". 
Penyimpangan terhadap asas konsensualisme dapat dilihat dari tahapan perjanjian yang meliputi pra kontraktual, kontraktual, dan post kontraktual. Pada tahap pra kontraktual yaitu sebelum perjanjian seharusnya terdapat kesepakatan mengenai berbagai persyaratan yang dibuat oleh kedua pihak. Dalam praktik pada umumnya konsumen (pemberi gadai) karena terdesak oleh kebutuhan tidak memperhatikan hak dan kewajibannya yang biasanya ditentukan secara tidak berimbang oleh pegadaian. Di samping itu perjanjian gadai swasta banyak dilakukan oleh perorangan dan dalam bentuk tidak tertulis. Hal demikian sangat menyulitkan dalam pembuktian jika terjadi sengketa. Apabila mendasarkan asas konsensualime bahwa perjanjian terjadi karena adanya kesepakatan para pihak, sedangkan dalam praktik ketentuan-ketentuan perjanjian dibuat secara sepihak oleh pihak pelaku usaha pegadaian dapat dikatakan bahwa dalam praktik pegadaian swasta terdapat kesepakatan semu. Perjanjian semacam ini disebut dengan perjanjian baku atau perjanjian standard.

Penyimpangan terhadap asas kebebasan berkontrak dapat dilihat dari tahap pra kontraktual, kontraktual maupun post kontraktual. Pada tahap pra kontraktual terdapat kesepakatan yang semu. Perjanjian pokok antara debitor dan debitor pada umumnya dibuat dalam bentuk baku, yang sudah ditentukan secara sepihak oleh pemegang gadai.

Pada tahap kontraktual, penyimpangan terhadap asas kebebasan berkontrak dapat dilihat dari isi perjanjian. Seharusnya sesuai dengan asas kebebasan berkontrak sebagaimana tersirat dalam Pasal 1338 KUH Perdata semua perjanjian harus terdapat kesepakatan antara para pihak mengenai isi perjanjian, bentuk perjanjian dan hukum yang berlaku. Namun demikian, dalam pelaksanaan perjanjian pokok yang dijamin dengan gadai swasta pada umumnya semua hak dan kewajiban para pihak ditentukan secara sepihak oleh pihak pegadaian swasta. Pada umumnya pihak pegadaian menentukan hak dan kewajiban yang tidak berimbang, karena lebih menekankan kewajiban-kewajiban nasabah daripada hak-haknya. Sebaliknya, hak-hak pegadaian lebih ditekankan daripada kewajibannya. Bahkan dalam praktik pegadaian swasta perjanjian pada umumnya tidak dibuat dalam bentuk tertulis. Hal ini tidak sesuai dengan Pasal 23 Ayat (1), (2) dan (3) POJK Nomor 31 /POJK.05/2016 Perusahaan Pegadaian wajib menyerahkan Surat Bukti Gadai kepada Nasabah pada saat menerima Barang Jaminan. Surat Bukti Gadai wajib disusun dengan memenuhi ketentuan perjanjian sebagaimana diatur dalam Peraturan OJK mengenai perlindungan konsumen sektor jasa keuangan. Perusahaan Pegadaian wajib menyimpan paling sedikit 1 (satu) salinan Surat Bukti Gadai untuk setiap transaksi.

Ketentuan Pasal 23 POJK Nomor 31 /POJK.05/2016 tersebut menunjukkan bahwa seharusnya perjanjian gadai dibuat dalam bentuk tertulis untuk memberikan bukti adanya perjanjian gadai antara pihak pemberi dan pemegang gadai. Hal ini akan memberikan kepastian hukum dan perlindungan hukum kepada para pihak, terutama pihak konsumen yang pada umumnya berada pada pihak yang memiliki bargaining position lemah. Dengan demikian akan lebih dapat memberikan keseimbangan hubungan hukum para pihak.

Pegadaian swasta seringkali dilakukan oleh perorangan, hal ini sangat berpotensi adanya berbagai penyimpangan dan menimbulkan kesulitan dalam pengawasan. Pegadaian swasta yang dilakukan oleh perorangan tidak sesuai dengan Pasal 1 Angka 2 dan 3 POJK Nomor 31 /POJK.05/2016. Pasal 1 Angka 2 POJK 31 /POJK.05/2016 menyebutkan bahwa Perusahaan Pegadaian adalah perusahaan pegadaian swasta dan 
perusahaan pegadaian pemerintah yang diatur dan diawasi oleh Otoritas Jasa Keuangan. Pasal 1 Angka 3 POJK Nomor 31 /POJK.05/2016 menyebutkan bahwa "Perusahaan Pegadaian Swasta adalah badan hukum yang melakukan Usaha Pegadaian." Dari ketentuan-ketentuan tersebut maka dapat disimpulkan bahwa seharusnya pegadaian swasta dilakukan oleh perusahaan yang berbadan hukum.

Penyimpangan asas hukum perjanjian pada tahap post kontraktual dapat dilihat pada pelaksanaan perjanjian dengan jaminan gadai pada pegadaian swasta. Pada pelaksanaan perjanjian dengan jaminan gadai seringkali dilakukan penggunaan manfaat terhadap objek gadai oleh pemegang gadai, yang sebenarnya hal tersebut bertentangan dengan asas hukum gadai dan jaminan kebendaan. Hak gadai merupakan hak jaminan kebendaan yang bersifat memberikan jaminan bukan hak kebendaan yang bersifat memberikan kenikmatan. Fungsi hak jaminan adalah untuk menjamin pelaksanaan prestasi debitor kepada kreditor. Hal ini tidak memberikan hak kepada pemegang hak jaminan untuk menggunakan kebendaan tersebut misalnya menyewakan atau menggunakan untuk keperluan dirinya. Dengan demikian terjadi penyalahgunaan benda gadai. Seharusnya pemegang gadai tidak boleh menyalahgunakan benda gadai. Hal ini ditentukan dalam Pasal 1159 ayat (1) KUH Perdata.

Penggunaan barang gadai oleh pemegang gadai sebagaimana diuraikan di atas juga bertentangan dengan Pasal 18 POJK Nomor 31 /POJK.05/2016 yang menyebutkan bahwa Perusahaan Pegadaian yang menyalurkan Uang Pinjaman berdasarkan hukum Gadai dilarang untuk:

a. menggunakan Barang Jaminan;

b. menyimpan Barang Jaminan di tempat Nasabah;

c. memiliki Barang Jaminan; dan/atau

d. menggadaikan kembali Barang Jaminan kepada pihak lain.

Dalam praktik gadai swasta yang dilakukan perorangan juga seringkali terjadi benda gadai dijual langsung oleh pemegang gadai dalam hal debitor tidak dapat membayar utangnya tanpa pemberitahuan kepada debitor atau benda gadai dimiliki langsung oleh pemegang gadai. Penjualan benda gadai seharusnya dilakukan dengan pemberitahuan (sommatie) terlebih dahulu kepada pemberi gadai. Penjualan benda gadai harus dilakukan di depan umum menurut kebiasaan setempat. Hal ini untuk memberikan perlindungan hukum kepada pemberi gadai. Mengenai larangan pemilikan benda gadai secara langsung oleh pemegang gadai terdapat ketentuan dalam Pasal 1154 KUH Perdata bahwa apabila pihak berutang atau pemberi gadai tidak memenuhi kewajibannya, maka tidak diperkenankan lah pihak yang berpiutang memiliki barang yang digadaikan. Segala janji yang bertentangan dengan ini batal demi hukum. Ketentuan selanjutnya dapat dilihat dalam Pasal 24 Ayat 7 POJK Nomor 31 /POJK.05/2016 menyebutkan bahwa "Barang Jaminan yang dijual oleh Nasabah sebelum tanggal Lelang, dilarang dibeli secara langsung maupun tidak langsung oleh Perusahaan Pegadaian atau pegawainya." Hal ini untuk memberikan perlindungan hukum kepada nasabah yang berkedudukan sebagai pemberi gadai, karena ada kemungkinan nilai barang gadai jauh lebih tinggi dari utang debitor.

Pemilikan benda gadai secara langsung oleh pemegang gadai jika debitor wanprestasi juga bertentangan dengan prinsip gadai, pemberi gadai dapat mengalami kerugian karena hak untuk memperoleh sisa hasil penjualan jika barang gadai dijual dan hasil penjualan tersebut setelah digunakan untuk melunasi utang debitor masih ada sisa 
menjadi hilang. Dalam penjualan benda gadai, pemegang gadai harus memperhitungkan hasil penjualan benda gadai dengan utang debitor. Apabila hasil penjualan benda gadai digunakan untuk melunasi utang debitor, masih ada sisa maka pemegang gadai wajib mengembalikan kepada pemberi gadai. Hal ini ditentukan secara jelas dalam Pasal 27 POJK Nomor 31 /POJK.05/2016 yang menyebutkan bahwa Perusahaan Pegadaian wajib mengembalikan Uang Kelebihan dari hasil penjualan Barang Jaminan dengan cara Lelang sebagaimana dimaksud dalam Pasal 26 atau berdasarkan kuasa menjual sebagaimana dimaksud dalam Pasal 24 ayat (3) huruf b kepada Nasabah. Sebaliknya kalau ada kekurangan, maka debitor harus melunasi sisa utangnya kepada kreditor. Pemberitahuan penjualan objek gadai dan perhitungan hasil penjualan objek gadai ini merupakan perwujudan asas itikad baik agar tidak ada penjualan benda gadai secara diam-diam. Di samping itu juga sebagai wujud dari asas keseimbangan dalam gadai.

Adanya berbagai penyimpangan terhadap asas-asas hukum perjanjian dan asas-asas hukum gadai maupun asas-asas hukum jaminan kebendaan serta tersebut berpotensi menimbulkan kerugian pada pihak pemberi gadai dan ketidakseimbangan hubungan hukum para pihak. Hal tersebut sangat merugikan masyarakat pada umumnya. Oleh karena itu reorientasi pelaksanaan gadai swasta sangat urgen untuk dilakukan agar pada masa mendatang pelaksanaan gadai swasta lebih memberikan perlindungan hukum kepada para pihak.

\section{Ketidakseimbangan Hubungan Hukum Para Pihak dalam Pelaksanaan Pegadaian Swasta}

Pegadaian swasta merupakan usaha pegadaian yang dilakukan oleh pihak swasta/ nonpemerintah. Kegiatan usaha pegadaian ini sama yang dilakukan oleh pegadaian pemerintah. Usaha yang dilakukan adalah pemberian pinjaman dengan jaminan benda bergerak, antara lain emas, barang elektronik, kendaraan bermotor dan sebagainya. Dasar hubungan hukum antara para pihak dalam perjanjian pinjam meminjam adalah perjanjian. Perjanjian antara debitor dengan kreditor sebagai pelaku usaha gadai swasta tersebut dijamin dengan jaminan kebendaan dengan objek benda bergerak dengan lembaga gadai.

Dalam gadai maka timbul hubungan hukum antara pemberi gadai (konsumen/ nasabah) dengan pemegang gadai (perusahaan pegadaian swasta). Dalam pelaksanaan pegadaian swasta terutama yang tidak terdaftar terdapat ketidakjelasan mengenai penaksiran benda jaminan, penyimpanan dan pemeliharaan benda jaminan, serta eksekusi benda jaminan. Hal demikian menimbulkan kurangnya kepastian hukum serta perlindungan hukum para pihak.

Adanya berbagai penyimpangan terhadap asas-asas hukum perjanjian dan asas-asas hukum gadai maupun asas-asas hukum jaminan kebendaan sebagaimana diuraikan pada bagian sebelumnya menunjukkan bahwa hal tersebut berpotensi menimbulkan kerugian pada pihak pemberi gadai dan ketidakseimbangan hubungan hukum para pihak. Hal tersebut sangat merugikan masyarakat pada umumnya. Ketidakseimbangan hubungan hukum tersebut dapat dilihat dari hal-hal sebagai berikut:

1. Terdapat pegadaian perorangan yang sangat rentan terhadap praktik rentenir yang pada umumnya mengenakan bunga yang tinggi dalam perjanjian utang piutang menjadikan pihak debitor sulit membayar utang. Akibatnyabenda gadai dijual oleh pihak pemegang gadai. 
2. Bendagadaidigunakandandinikmatiolehpemeganggadaibaikuntukkeperluan pribadi maupun usaha seperti disewakan, dan sebagainya. Fungsi gadai sebagaimana lembaga jaminan pada umumnya adalah untuk menjamin pelaksanaan prestasi debitor. Oleh karenaituhakkebendaanyangdiperoleholehpemeganggadaimerupakanhakkebendaan yang bersifat memberikan jaminan, bukan hak kebendaan yang bersifat memberikan kenikmatan. Pasal 1159 Selama pemegang gadai itu tidak menyalahgunakan barang yang diberikan kepadanya sebagai gadai, debitur tidak berwenang untuk menuntut kembali barang itu sebelum ía membayar penuh, baik jumlah utang pokok maupun bunga dan biaya utang yang dijamin dengan gadai itu, beserta biaya yang dikeluarkan untuk penyelamatan barang gadai itu. Dari peraturan tersebut dimaknai secara $a$ contrario bahwa pemegang gadai tidak boleh menyalahgunakan benda gadai. Apabila terjadi penyalahgunaan benda gadai maka secara otomatis gadai menjadi hapus, dan benda gadai wajib dikembalikan kepada pemberi gadai.

3. Eksekusi benda gadai yang dilakukan tidak dengan lelang. Penjualan tidak dengan lelang dapat menimbulkan ketidakadilan, karena tidak di depan masyarakat umum.

4. Sisa penjualan benda gadai tidak diserahkan kembali kepada pemberi gadai.

5. Pemegang gadai memiliki benda gadai pada waktu debitor wanprestasi. Tindakan demikian dapat menimbulkan ketidakadilan bagi pemberi gadai. Hal ini bertentangan dengan prinsip gadai bahwa apabila pemberi gadai (debitor) tidak melaksanakan kewajibannya (wanprestasi), maka kreditor tidak boleh memiliki barang yang digadaikan. ${ }^{12}$ Segala janji yang bertentangan dengan ketentuan tersebut adalah batal (Pasal 1134 KUH Perdata). Hal demikian adalah untuk memberikan perlindungan hukum kepada pemberi gadai, agar pemegang gadai tidak bertindak sewenang-wenang, karena pada umumnya nilai objek gadailebih tinggi daripada utang debitor. Seharusnya apabila dari hasil penjualan benda gadai ada sisa setelah dikurangi piutang kreditor, maka pemegang gadai harus mengembalikan sisanya tersebut kepada pemberi gadai. Hal itu merupakan hak dari pemberi gadai. Menurut Achmad Ali terdapat tiga unsur dalam hak, yaitu perlindungan, pengakuan dan kehendak. ${ }^{13}$

Hal-hal tersebut di atas menunjukkan bahwa telah terjadi ketidakseimbangan hubungan hukum para pihak dan berbagai penyimpangan terhadap prinsip gadai dan perjanjian. Hal ini seringkali menimbulkan kerugian pada pihak pemberi jaminan. Oleh karena itu perlu adanya pengawasan pegadaian swasta secara intensif. Dalam hal pegadaian swasta sudah terdaftar, dapat dilakukan pengawasan oleh OJK, namun untuk pegadaian swasta yang belum terdaftar OJK tidak memiliki kewenangan untuk mengawasi. Hal ini menimbulkan ketidakpastian hukum dan dapat menimbulkan ketidakadilan serta kurangnya perlindungan hukum bagi masyarakat pengguna jasa pegadaian swasta.

Berdasarkan hal-hal di atas maka pada masa mendatang diperlukan adanya pengawasan secara terintegrasi antara pemerintah, pelaku usaha dan masyarakat agar dalam pelaksanaan usaha pegadaian swasta terdapat hubungan hukum yang seimbang antara para pihak dan sesuai dengan prinsip gadai, asas-asas hukum jaminan serta perjanjian pada umumnya, yang mencerminkan nilai-nilai dasar yang terkandung dalam Pancasila sebagai sumber dari segala sumber hukum di Indonesia.

${ }^{12}$ P.N.H. Simanjuntak, 2015, Hukum Perdata Indonesia, Cet. Ke-1, Prenadamedia Group, Jakarta, hlm. 199

${ }^{13}$ Achmad Ali, 2015, Menguak Tabir Hukum, Cet. Ke-2, Kencana, Jakarta, hlm. 260. 


\section{SIMPULAN}

Berdasarkan uraian di atas maka dapat disimpulkan bahwa munculnya pegadaian swasta dalam dunia usaha pada satu sisi dapat menjadi alternatif pembiayaan yang bermanfaatbagi masyarakat, karena dapat menjadi sumber pembiayaan untuk kebutuhan konsumtif maupun produktif dengan proses yang mudah dan sederhana. Kemudahan dan kesederhanaan proses pegadaian swasta menjadi daya tarik besar bagi masyarakat yang membutuhkan dana untuk mencukupi kebutuhannya. Namun demikian ternyata dalam pelaksanaan belum banyak Usaha Pegadaian Swasta yang melakukan pendaftaran ke Otoritas Jasa Keuangan. Hal demikian menjadikan tidak dapat diawasi secara jelas. Sebagai akibatnya adanya berbagai penyimpangan terhadap asas-asas hukum gadai, asas-asas hukum jaminan kebendaan maupun perjanjian, maka pada pelaksanaan gadai swasta terjadi ketidakseimbangan hubungan hukum para pihak yang bermuara pada ketidakadilan.

\section{DAFTAR PUSTAKA}

\section{Buku}

Achmad Ali, (2015), Menguak Tabir Hukum, Edisi Kedua, Kencana, Jakarta.

Mariam Darus Badrulzaman, (2018), Hukum Harta Kekayaan Indonesia Didalam Perkembangan, edisi 1, PT Citra Aditya Bakti, Bandung.

P.N.H. Simanjuntak, (2015), Hukum Perdata Indonesia. I. Prenadamedia Group, Jakarta.

\section{Jurnal dan Karya Ilmiah Lain}

Ainon Marziah, Sri Walny Rahayu, and Iman Jauhari, (2019), Pembuktian Risalah Lelang Bagi Pemenang Eksekusi Hak Tanggungan (Proof The Minutes Of Auction For The Winner Of Execution Of Mortgage Rights), Jurnal IUS, Kajian Hukum dan Keadilan, vol 7, no 2.

Andryushchenko G.I., A.M. Andryushchenko, A.N. Maloletko, M.V. Savina and P.V. Solodukha (2017). Risks of Developing the Pawnshops Market in the Russian Federation, International Journal of Applied Business and Economic Research, , 15 , no. 8.

Annisa Hanifah, Budi Santoso, and Ismail Navianto (2018), Urgensi Pengaturan Perusahaan Gadai Swasta Dengan Sistem Online, Al-Mustashfa, Jurnal Penelitian Hukum Ekonomi Syariah,vol 3, no 1.

Christopher Gan, Zhaohua li, Weizhuo Wang, and Betty Kao (2012), Credit Scoring in Mortgage Lending: Evidencefrom China, InternationalJournalofHousing Markets and Analysis,vol 5, no 4, hlm. 334-350. doi:10.1108/17538271211268457.

Lastuti Abubakar, dan Tri Handayani, (2017), Telaah Yuridis Perkembangan Regulasi Dan Usaha Pegadaian Sebagai Pranata Jaminan Kebendaan, Jurnal Bina Mulia Hukum, vol 2, no 35, hlm. 80-92. doi:10.23920/jbmh.v2n1.7.

Novianti Ekatama, (2014), Prospek Usaha Pegadaian dalam Menghadapi Lembaga Perkreditan di Indonesia, Jurnal Repertorium, vol 1, no 2.

Siti Malikhatun Badriyah, (2016), Problematika Pembebanan Hak Tanggungan Dengan Objek Tanah Yang Belum Bersertipikat, Jurnal Masalah - Masalah Hukum, vol 
45 , no 3.

Sumit Agarwal, Richard K. Green, Eric Rosenblatt, dan Vincent Yao, (2015), Collateral Pledge, Sunk-Cost Fallacy and Mortgage Default, Journal of Financial Intermediation, vol 24, no 4, hlm. 636-52. doi:10.1016/j.jfi.2014.10.001.

Sawotong, Dilva Muzdaliva, (2014), Jaminan Kebendaan Pada PT. Pegadaian Terhadap Barang Yang Digadaikan, Lex Privatum,vol 2, no 1.

\section{Peraturan Perundang-undangan}

Kitab Undang-undang Hukum Perdata

Peraturan Otoritas Jasa Keuangan No 31 /POJK.05/2016 Tentang Usaha Pegadaian

\section{Website}

Luthfia Ayu Azanella, (2018), Perjalanan Bisnis Gadai Dari Masa Ke Masa." Kompas. Com. https://ekonomi.kompas.com/read/2018/05/30/070000126/perjalananbisnis-gadai-dari-masa-ke-masa-. Diakses pada tanggal 22 Agustus 2019. 